\title{
EFFICIENCY OF GASEOUS OZONE IN DISINFECTION OF MUSHROOM GROWING ROOMS
}

\author{
Joanna SZUMIGAJ-TARNOWSKA ${ }^{1 *}$, Piotr SZAFRANEK ${ }^{2}$, \\ Zbigniew ULIŃSKI ${ }^{1}$, Czesław ŚLUSARSKI ${ }^{1}$ \\ ${ }^{1}$ Research Institute of Horticulture, Konstytucji 3 Maja 1/3 St., 96-100 Skierniewice, Poland \\ ${ }^{2}$ Agency for Restructuring and Modernisation of Agriculture, Poleczki 33 St., 02-822 Warsaw, Poland
}

Received: March 2020; Accepted: September 2020

\begin{abstract}
Fungal diseases are a persistent problem in the cultivation of white button mushrooms (Agaricus bisporus). The chemical control of pathogens is becoming less effective and less desirable, so new ways to limit these infections are urgently required. What is more, the disease is mostly controlled through cultural practices and good hygiene on mushroom farms. The aim of this study was to evaluate the fungicidal effects of ozone on fungal pathogens of common mushrooms. Experiments with the use of ozone gas for disinfection of growing rooms after the completion of the mushroom growing cycle were carried out. The fungicidal effectiveness of ozone fumigation was evaluated on the basis of the survival rate of the spores of the pathogens tested (Lecanicillium fungicola, Cladobotryum dendroides, Mycogone perniciosa, and Trichoderma aggressivum). Spore suspension was applied to aluminum plates and then was exposed to gaseous ozone. The assessment of the growth of colonies of fungal isolates obtained from infected surfaces was carried out using Rodac contact test plates. The results showed that L. fungicola, M. perniciosa, and C. dendroides isolates were sensitive to the gas ozone. In order to achieve 100\% efficacy against Mycogone strains, a minimum of 6 hours of ozonation had to be applied, whereas for Cladobotryum strains, a minimum of 8 hours had to be applied. The Lecanicillium species was the most sensitive to ozonation because 30 minutes of ozonation was enough to gain $100 \%$ inhibition of its growth. No satisfactory results were obtained in the case of the pathogenic species of Trichoderma, regardless of the experimental conditions. Nevertheless, this study has demonstrated the usefulness of ozone as a disinfectant for empty growing rooms after the completion of the mushrooms' cultivation cycle.
\end{abstract}

Key words: Agaricus bisporus, fungal pathogens, ozonation, control

\section{INTRODUCTION}

Button mushroom Agaricus bisporus Lange (Imbach) is a widely cultivated edible mushroom in the world (Sánchez 2010, Kaliyaperumal et al. 2018, Kapahi 2018). Commodity cultivation of these fungi in modern mushroom houses takes place throughout the year in halls specially adapted for running only this type of crop. This ensures optimum conditions for the development of mycelium and fruiting throughout the production stage, which allows to obtain high yields and high-quality products. On the other hand, long-term intensive cultivation in monoculture is conducive to the appearance of diseases and pests (Fletcher \& Gaze 2008).
The most common pathogens in the cultivation of button mushroom are Trichoderma aggressivum, Cladobotryum dendroides, Mycogone perniciosa, and Lecanicillium fungicola (Fletcher \& Gaze 2008, Berendsen et al. 2010). The losses caused by these pathogens are varied and depend on the moment of their occurrence in the mushroom crop and the number of fungal spores (Szumigaj-Tarnowska et al. 2011, Szumigaj-Tarnowska et al. 2015, Ślusarski et al. 2013).

An important element of crop protection against pathogens in mushroom houses is the "cooking-out" of production halls after each cultivation cycle, using steam to heat the air in the hall to a temperature of $65-70{ }^{\circ} \mathrm{C}$ and keeping it for at least 8 hours. 
This treatment allows to kill all mushroom pathogens and pests even deep inside the substrate and the peat cover (Ekman 2017). However, not all mushroom farms have technical capabilities to carry out this treatment (Ślusarski et al. 2012).

In this case, an alternative is chemical disinfection of the hall, which is a less effective but cheaper and easier method to use. The aim of disinfection is to reduce the pathogen population or to eliminate them completely. However, even a high concentration of biocides operating for a prolonged period cannot completely reduce pathogen populations in mushroom substrate. This treatment can be more effective when it is used on the surface thoroughly cleaned of mushroom debris or any other organic contamination (O’Neill et al. 2015).

Gaseous ozone was granted generally recognized as safe status by the Food and Drug Administration for direct contact with food as a sanitizing agent. Ozone is a very strong oxidant that has long been used to disinfect drinking water and wastewater (Rodríguez et al. 2008). It is also used as a disinfectant in the food industry and for removing unpleasant odors in rooms (Skalska et al. 2006, Krosowiak et al. 2007). In horticulture, it is successfully used in fruit and vegetable storage (Krosowiak et al. 2007) as well as in the disinfection of media in recirculating hydroponic systems (Vanachter et al. 1988). Ozone can also be used in the production of a substrate for cultivated mushrooms (Buntat et al. 2013) and to reduce the occurrence of disease during the course of the cultivation cycle (Toto 2010). Gaseous ozone is also suitable for reduction of microorganisms that can occur on food, including mushrooms, such as Salmonella spp., Listeria monocytogenes, and Escherichia coli O157:H7 (Akata et al. 2015). There were also attempts to apply ozone to extend the shelf life of button mushrooms, but the problem was browning of mushrooms under the influence of gas (Skog \& Chu 2001, Escriche et al. 2001).

Investigation on the possibility of using ozone to control fungal pathogens occurring in the mushroom cultivation has been undertaken only once so far and concerned only one species. O'Neill et al. (2015) showed the lack of efficiency of ozone gas in mycelium and spores of T. aggressivum.
There is thus a need for extended efficacy evaluation of gaseous ozone for reducing the other most common fungal pathogens of white button mushrooms. However, due to the high sensitivity of mushrooms to browning under the influence of ozone, it is worth considering the possibility of using it after harvest at the end of the production cycle.

The aim of the study was to determine the efficiency of ozone gas for disinfection of empty growing rooms between production cycles in order to reduce the most important fungal diseases occurring in the mushroom cultivation.

\section{MATERIALS AND METHODS}

\section{Fungal strains}

Strains of T. aggressivum (Th 3.9, Th 12, Th 22.07), C. dendroides (D12A, D16, D30), M. perniciosa (M9, M10, M18), and L. fungicola (V3, V17, V31) were selected from samples of infected mushroom compost and infected mushrooms collected from mushroom houses located in different regions of Poland (Table 1). For isolation of the pathogens, except for Trichoderma isolates, $5 \mathrm{~mm}$ discs of infected sporophore tissue with the help of sterilized scalpel were taken and placed on a potato dextrose (PDA) medium supplemented with $50 \mathrm{mg} \cdot \mathrm{dm}^{-3}$ of streptomycin and $5 \mathrm{mg} \cdot \mathrm{dm}^{-3}$ rifampicin. For isolation of Trichoderma isolates, the samples of infected mushroom compost were placed on the PDA medium. Mycelium of isolates was grown at 23$24{ }^{\circ} \mathrm{C}$ for 1 week. For further studies, the isolates were maintained for a short term on the PDA medium at $4{ }^{\circ} \mathrm{C}$ and on the PDA medium placed in $15 \% \mathrm{v} / \mathrm{w}$ glycerol at $-75{ }^{\circ} \mathrm{C}$ for long storage. Before analysis, the isolates were activated on the PDA medium in the temperature range $23-24^{\circ} \mathrm{C}$. Once a year, fungal isolates were inoculated on the mushroom compost to enhance their pathogenicity.

The identification of the isolated fungi was based on morphological characteristics as well as on growth rates and features of the colony on various agar media. To confirm the identification of pathogens, a molecular analysis was conducted (Szczech et al. 2008; Trzewik et al. 2010; Szumigaj-Tarnowska et al. 2014). 
Table 1. List of isolates used in this study and their origin

\begin{tabular}{cccc}
\hline Species & Isolate code & Province & Year of collection \\
\hline \multirow{3}{*}{ Trichoderma aggressivum } & Th 3.9 & Mazowieckie & 2008 \\
& Th.12 & Mazowieckie & 2009 \\
& Th 22.07 & Lódzkie & 2005 \\
Mycogone perniciosa & M9 & Mazowieckie & 2008 \\
& M10 & Podkarpackie & 2008 \\
& M18 & Lódzkie & 2009 \\
Cladobotryum dendroides & D12A & Wielkopolskie & 2008 \\
& D16 & Wielkopolskie & 2008 \\
& D30 & Mazowieckie & 2008 \\
Lecanicillium fungicola & V-3 & Mazowieckie & 2005 \\
& V-17 & Mazowieckie & 2009 \\
& V-31 & Lódzkie & 2010 \\
\hline
\end{tabular}

\section{Inoculum preparation}

Each tested strain was transplanted from stock culture on the PDA plate and kept at $24^{\circ} \mathrm{C}$ for 5-7 days. Subsequently, when the diameter of the colony reached a minimum of $1 / 3$ of the plate surface, it was re-transplanted. New plates were maintained at $24{ }^{\circ} \mathrm{C}$ for $7-14$ days. Suspensions were prepared by adding sterile distilled water to plates and detaching the spores from the surface of the colonies using a glass spreader. Then the suspensions were poured into a sterile flask. The concentration of spores of each strain was adjusted to $10^{6}$ spores $\mathrm{ml}^{11}$ by dilution and direct counting using a Thoma cell counting chamber.

\section{Experimental method}

Suspensions containing spores of individual pathogens were applied to aluminum plates in an amount of $0.1 \mathrm{ml}$. Each spore suspension was applied to eight plates and allowed to dry in the laminar chamber. Then four plates were covered with petri dishes and moved to the mushroom growing room; the petri dishes were removed and fungal spores were exposed to gaseous ozone. Experiments were carried out in the mushroom hall with a capacity of $130 \mathrm{~m}^{3}$. The relative humidity was maintained at $90 \%$. Gaseous ozone was produced using an ozone generator (DST 50, BLUE PLANET, Poland) with a capacity of $50 \mathrm{~g} \cdot \mathrm{h}^{-1}$. Ozone concentration was measured using an ozone concentration sensor (GasHunter, Alter, Poland), which is an online monitoring system.
Samples were subjected to ozonation at the temperature $18 \pm 0.5^{\circ} \mathrm{C}$ for six exposure times $-30,60$, $120,240,360$, and 480 minutes. The gas concentration during the ozonation process is shown in Fig. 1. The maximum level of ozone reached $50 \mathrm{ppm}$ within 6 hours and was maintained at this level during the next 2 hours. After the ozonation process, aluminum surfaces were sampled by placing agar Rodac plates in contact for 10 seconds and then placing them in an incubator at $24{ }^{\circ} \mathrm{C}$ for 7 days.

The plates were viewed daily for 7 days. The diameter of pathogen colonies was determined as well as pollution (as a percentage of the plate surface) caused by other fungal species.

\section{Statistical analysis}

The experiments were performed twice in four replications. Efficiency of ozonation was determined on the basis of pathogen growth on the plate in relation to the control combination and the means were compared using Student's t-test at the level of significance of $p=0.05$.

The comparison of the percentage of isolate growth inhibition in relation to ozone exposure time, within incubation day, was subjected to analysis of variance according to Duncan's multiple range test at the level of significance of $p \leq 0.05$ in Statistica version 10 software. To evaluate the relation between the time of ozone exposure and inhibition of growth of the pathogen colony, a regression method was used and Pearson's correlation coefficients (r-values) were calculated. 


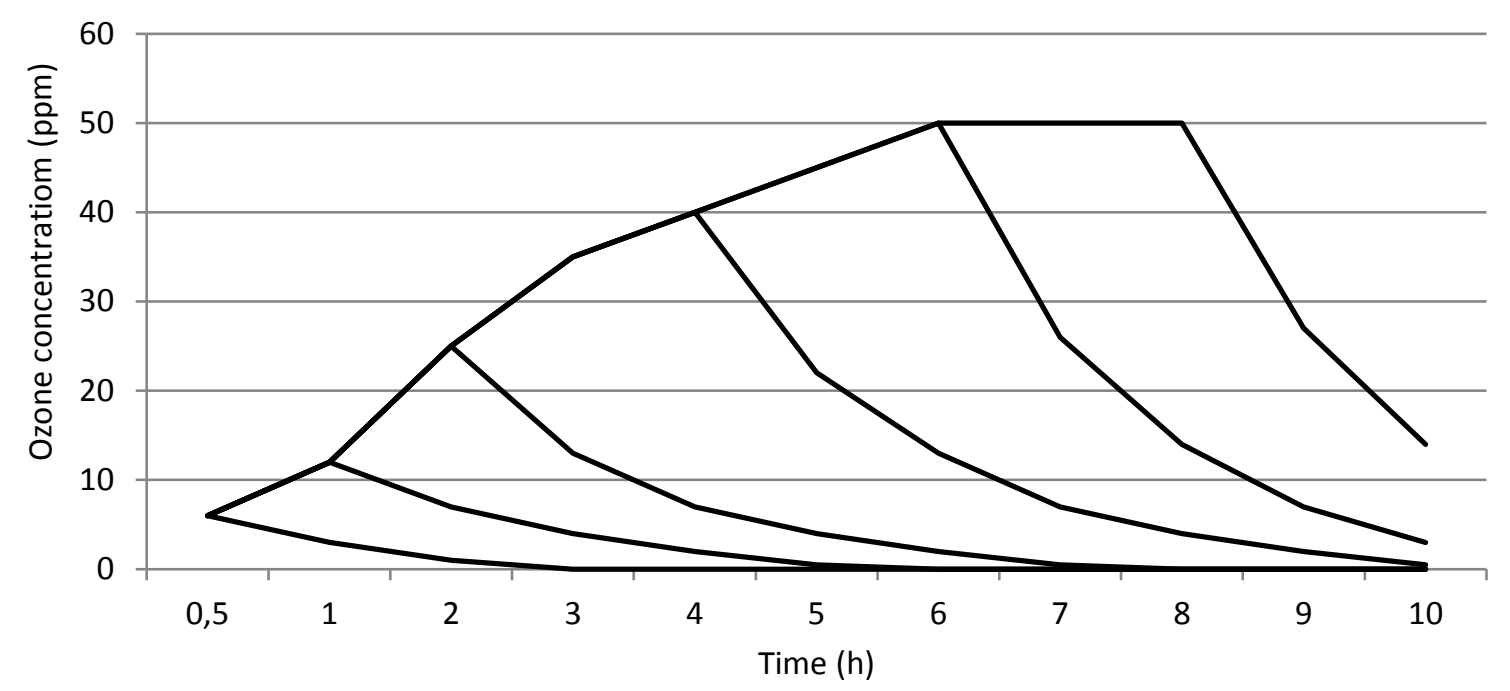

Fig. 1. The gas concentration during the ozonation process at different exposure times

\section{RESULTS AND DISCUSSION}

Green mold caused by T. aggressivum has been a major disease affecting mushroom production (O'Brien et al. 2017). During our study, Trichoderma isolates proved to be the most resistant to ozone among the pathogens tested (Table 2; Fig. 2). Only one of three tested isolates of this species was damaged after 6 hours of ozonation (Table 3). These differences in ozone sensitivity among isolates of the same species were also observed by AntonyBabu and Singleton (2009). They reported that only one isolate exposed to a continuous low level of ozone did not produce spores, whereas another isolate only delayed spore production by a day compared to the control.

What is more, the results obtained confirm earlier information on the high resistance of green molds to ozone. O'Neill et al. (2015) reported that gaseous ozone is completely ineffective in relation to the spores and mycelium of T. aggressivum. Conditions in which the researchers conducted experiments were different than those in the presented work. The exposure time was definitely shorter (maximum 80 minutes), and higher ozone concentrations were obtained (up to $100 \mathrm{ppm}$ ). The experiment was also carried out at a lower air humidity of around $70 \%$. In such conditions, however, ozone gas showed quite good effectiveness with respect to the mushroom mycelium. A comparison of ozone with other chemical disinfectants used in mushroom houses shows that gaseous ozone is the least effective of them. The high tolerance of Trichoderma to ozone was demonstrated also by Hudson and Sharma (2009). What is important, Baars and Rutjens (2016) also confirm the lack of efficiency of ozone as a disinfectant, while suggesting that it can stimulate spore germination. In our research, however, we did not confirm this statement. The growing rate as well as the time of appearance of the first colonies of Trichoderma isolates on ozone plates was at a similar level (Table 3). This finding also could have been applied to other tested pathogens (Tables $4 \& 5$ ). Slightly different results regarding the efficiency of ozone in relation to molds occurring on button mushrooms have been obtained by Akata et al. (2015). Exposure to gaseous ozone at a concentration of $5.3 \mathrm{mg} \cdot \mathrm{dm}^{-3}$ for 45 minutes resulted in a decrease in mold count below the detection limit $(<2 \log$ CFU per mushroom) with a reduction of more than $1.43 \mathrm{log}$. Unfortunately, the authors did not provide the exact mold species, which makes it difficult to compare both results. Molds that occur on mushrooms can belong to different species, such as Trichoderma, Penicillium, Pythium, and others (Fletcher \& Gaze 2008), and as our result suggests, differences in response to ozone occur even between isolates of the same species (Fig. 3). 
Table 2. Sensitivity of pathogenic species to ozonation based on the average rate of colonization of the plate area $(\%)$ after 5 days of incubation in relation to ozone exposure time

\begin{tabular}{cccccccc}
\hline \multirow{2}{*}{ Species } & Treatment & \multicolumn{6}{c}{ Time of exposure } \\
\cline { 3 - 8 } Trichoderma & Control & $86.2 \pm 7.3 \mathrm{a}$ & $78.8 \pm 6.9 \mathrm{a}$ & $74.6 \pm 5.2 \mathrm{a}$ & $76.7 \pm 8.0 \mathrm{a}$ & $77.1 \pm 7.6 \mathrm{a}$ & $76.7 \pm 8.3 \mathrm{a}$ \\
aggressivum & Ozone & $31.7 \pm 8.4 \mathrm{~b}$ & $63.1 \pm 6.5 \mathrm{a}$ & $59.2 \pm 9.7 \mathrm{a}$ & $73.7 \pm 5.8 \mathrm{a}$ & $75.0 \pm 4.9 \mathrm{a}$ & $73.3 \pm 4.4 \mathrm{a}$ \\
\hline Mycogone & Control & $55.0 \pm 5.6 \mathrm{a}$ & $52.5 \pm 5.9 \mathrm{a}$ & $65.0 \pm 4.4 \mathrm{a}$ & $55.8 \pm 8.0 \mathrm{a}$ & $55.4 \pm 2.8 \mathrm{a}$ & $54.6 \pm 6.2 \mathrm{a}$ \\
perniciosa & Ozone & $0.0 \pm 0.0 \mathrm{~b}$ & $0.0 \pm 0.0 \mathrm{~b}$ & $44.5 \pm 4.5 \mathrm{a}$ & $42.5 \pm 6.3 \mathrm{a}$ & $52.9 \pm 4.0 \mathrm{a}$ & $52.5 \pm 5.5 \mathrm{a}$ \\
\hline Cladobotryum & Control & $70.4 \pm 3.4 \mathrm{a}$ & $60.0 \pm 7.9 \mathrm{a}$ & $67.9 \pm 5.3 \mathrm{a}$ & $72.1 \pm 6.9 \mathrm{a}$ & $70.8 \pm 3.9 \mathrm{a}$ & $67.1 \pm 3.6 \mathrm{a}$ \\
dendroides & Ozone & $0.0 \pm 0.0 \mathrm{~b}$ & $22.1 \pm 1.4 \mathrm{~b}$ & $63.7 \pm 4.5 \mathrm{a}$ & $70.4 \pm 5.5 \mathrm{a}$ & $69.2 \pm 4.3 \mathrm{a}$ & $63.3 \pm 5.0 \mathrm{a}$ \\
\hline Lecanicillium & Control & $23.4 \pm 3.1 \mathrm{a}$ & $23.1 \pm 2.6 \mathrm{a}$ & $24.7 \pm 3.3 \mathrm{a}$ & $26.2 \pm 2.1 \mathrm{a}$ & $25.3 \pm 2.8 \mathrm{a}$ & $25.8 \pm 3.7 \mathrm{a}$ \\
fungicola & Ozone & $0.0 \pm 0.0 \mathrm{~b}$ & $0.0 \pm 0.0 \mathrm{~b}$ & $0.0 \pm 0.0$ & $0.0 \pm 0.0 \mathrm{~b}$ & $0.0 \pm 0.0$ & $0.0 \pm 0.0$ \\
\hline
\end{tabular}

Means in columns followed by the same letter, for particular pathogen, are not significantly different based on Student's t-test at $\mathrm{p}=0.05$. Values are means \pm standard deviation, $\mathrm{n}=24$

Table 3. Sensitivity of Trichoderma aggressivum isolates to ozonation, based on the percentage of growth inhibition

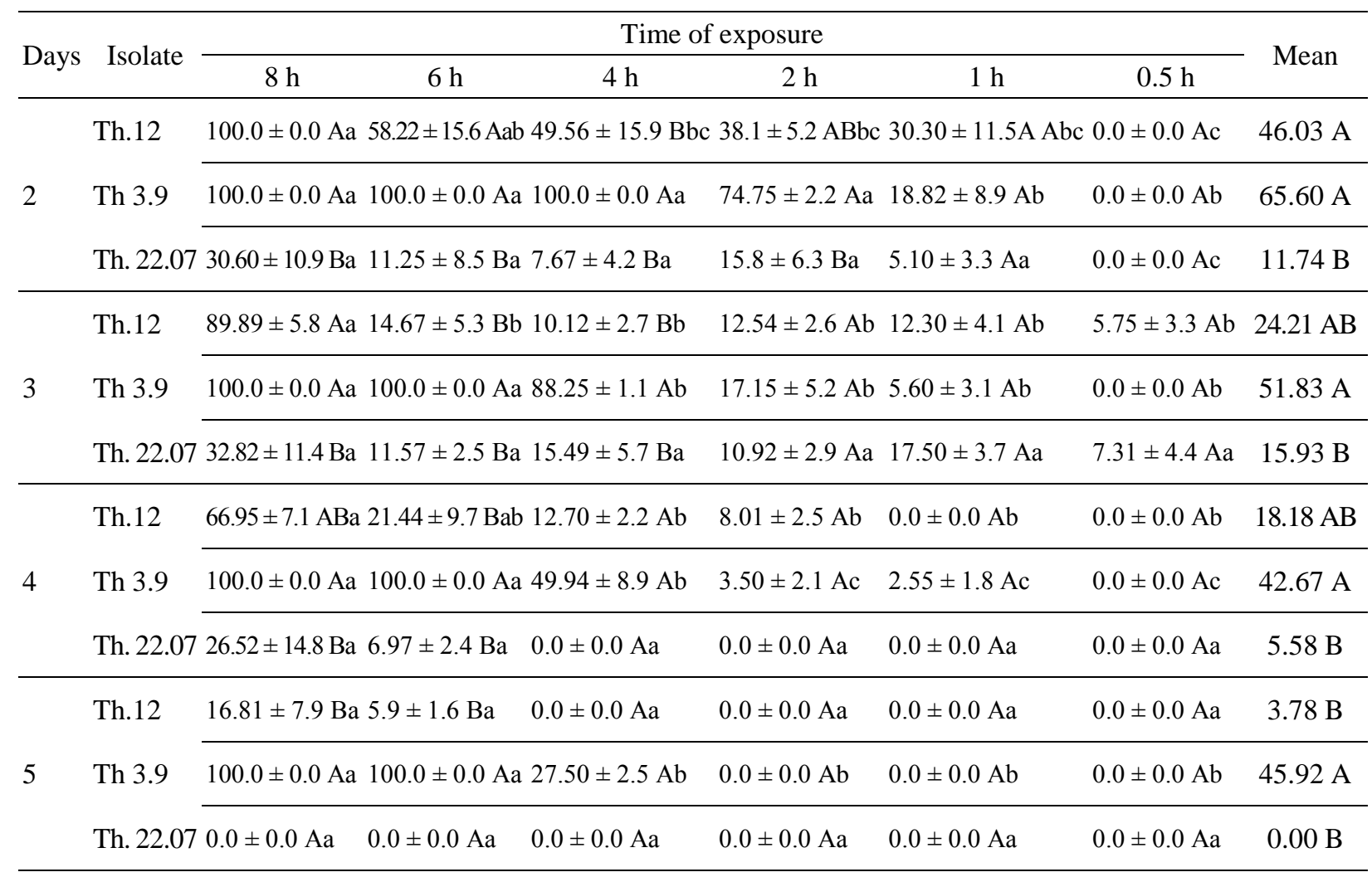

A, B, C - Means in columns followed by the same letter, within days of incubation, are not significantly different according to Duncan's test $(\mathrm{P} \leq 0.05)$; Means \pm standard deviation. a, b, c - Means in rows followed by the same letter, within days of incubation, are not significantly different according to Duncan's test $(\mathrm{P} \leq 0.05)$; Means \pm standard deviation 


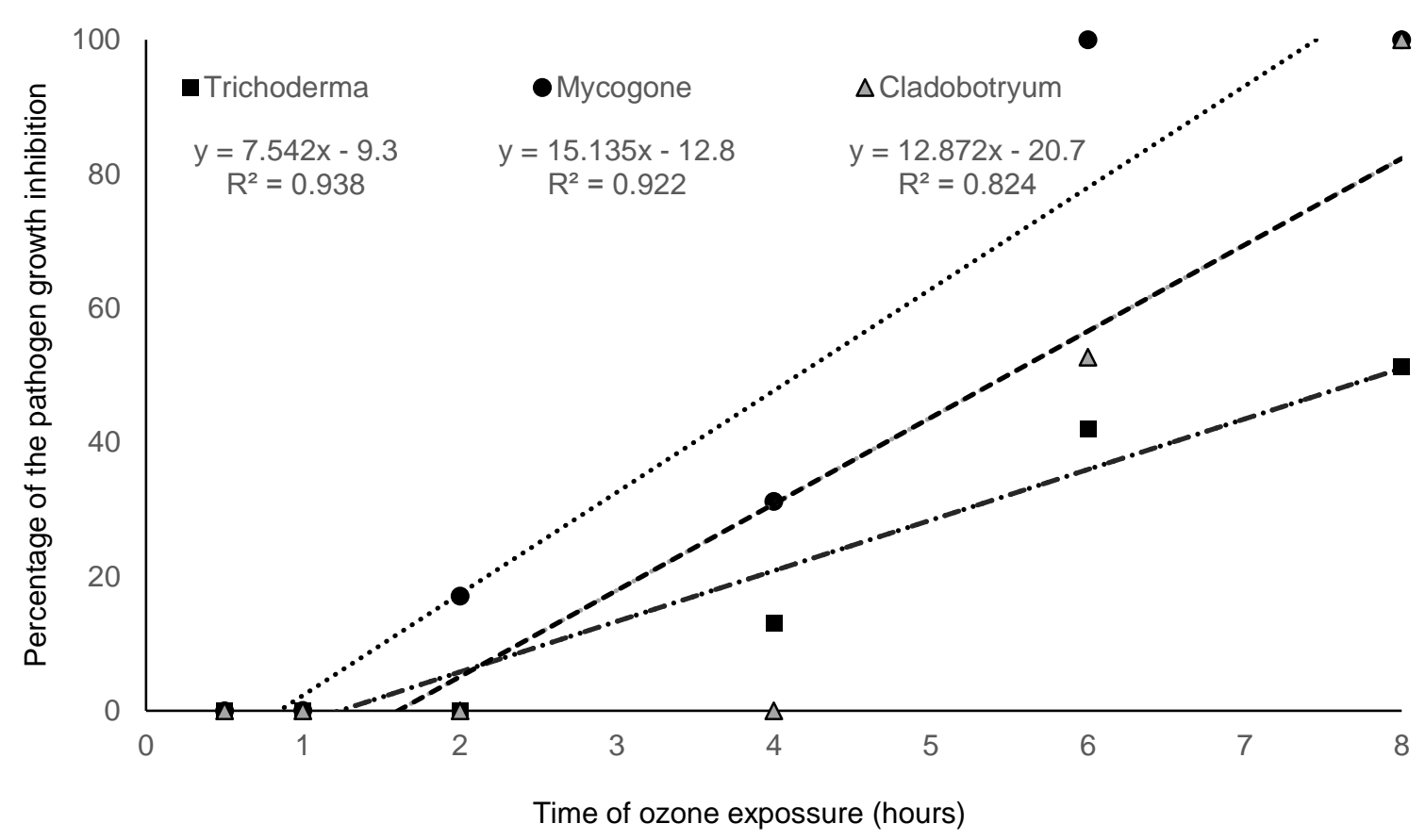

Fig. 2. Effect of ozone exposure duration on the percentage of the colony growth inhibition of tested pathogens

Table 4. Sensitivity of Cladobotryum dendroides isolates to ozonation, based on the percentage of growth inhibition

\begin{tabular}{|c|c|c|c|c|c|c|c|}
\hline \multirow{2}{*}{ Days } & \multirow{2}{*}{ Isolate } & \multicolumn{5}{|c|}{ Time of exposure } & \multirow{2}{*}{ Mean } \\
\hline & & $6 \mathrm{~h}$ & $4 \mathrm{~h}$ & $2 \mathrm{~h}$ & $1 \mathrm{~h}$ & $0.5 \mathrm{~h}$ & \\
\hline \multirow{3}{*}{2} & D12A & $100.0 \pm 0.0 \mathrm{Aa} 100.0 \pm 0.0 \mathrm{Aa}$ & $0.0 \pm 0.0 \mathrm{Ab}$ & $0.0 \pm 0.0 \mathrm{Ab}$ & $0.0 \pm 0.0 \mathrm{Ab}$ & $0.0 \pm 0.0 \mathrm{Ab}$ & $33.33 \mathrm{~A}$ \\
\hline & D16 & $100.0 \pm 0.0 \mathrm{Aa} 100.0 \pm 0.0 \mathrm{Aa}$ & $0.0 \pm 0.0 \mathrm{Ab}$ & $0.0 \pm 0.0 \mathrm{Ab}$ & $0.0 \pm 0.0 \mathrm{Ab}$ & $0.0 \pm 0.0 \mathrm{Ab}$ & $33.33 \mathrm{~A}$ \\
\hline & D30 & $100.0 \pm 0.0 \mathrm{Aa} 46.30 \pm 15.5 \mathrm{Aab}$ & $29.7 \pm 5.2 \mathrm{Ab}$ & $0.0 \pm 0.0 \mathrm{Ab}$ & $0.0 \pm 0.0 \mathrm{Ab}$ & $0.0 \pm 0.0 \mathrm{Ab}$ & $29.33 \mathrm{~A}$ \\
\hline \multirow{3}{*}{3} & D12A & $100.0 \pm 0.0 \mathrm{Aa} 100.0 \pm 0.0 \mathrm{Aa}$ & $20.67 \pm 3.5 \mathrm{Ab}$ & $0.0 \pm 0.0 \mathrm{Ab}$ & $0.0 \pm 0.0 \mathrm{Ab}$ & $0.0 \pm 0.0 \mathrm{Ab}$ & $36.78 \mathrm{~A}$ \\
\hline & D16 & $100.0 \pm 0.0 \mathrm{Aa} 100.0 \pm 0.0 \mathrm{Aa}$ & $13.29 \pm 2.0 \mathrm{Ab}$ & $0.0 \pm 0.0 \mathrm{Ab}$ & $0.0 \pm 0.0 \mathrm{Ab}$ & $0.0 \pm 0.0 \mathrm{Ab}$ & $35.55 \mathrm{~A}$ \\
\hline & D30 & $100.0 \pm 0.0$ Aa $31.88 \pm 9.2 \mathrm{Aab}$ & $20.87 \pm 8.2 \mathrm{Ab}$ & $5.50 \pm 2.5 \mathrm{Ab}$ & $0.0 \pm 0.0 \mathrm{Ab}$ & $0.0 \pm 0.0 \mathrm{Ab}$ & $26.38 \mathrm{~A}$ \\
\hline \multirow{3}{*}{4} & $\mathrm{D} 12 \mathrm{~A}$ & $100.0 \pm 0.0 \mathrm{Aa} 100.0 \pm 0.0 \mathrm{Aa}$ & $10.75 \pm 5.5 \mathrm{Ab}$ & $0.0 \pm 0.0 \mathrm{Ab}$ & $0.0 \pm 0.0 \mathrm{Ab}$ & $0.0 \pm 0.0 \mathrm{Ab}$ & $35.12 \mathrm{~A}$ \\
\hline & D16 & $100.0 \pm 0.0 \mathrm{Aa} 100.0 \pm 0.0 \mathrm{Aa}$ & $18.39 \pm 7.1 \mathrm{Ab}$ & $11.38 \pm 4.5 \mathrm{Ab}$ & $0.0 \pm 0.0 \mathrm{Ab}$ & $0.0 \pm 0.0 \mathrm{Ab}$ & $38.30 \mathrm{~A}$ \\
\hline & D30 & $100.0 \pm 0.0 \mathrm{Aa} 12.92 \pm 5.0 \mathrm{Ab}$ & $13.20 \pm 6.6 \mathrm{Ab}$ & $0.0 \pm 0.0 \mathrm{Ab}$ & $0.0 \pm 0.0 \mathrm{Ab}$ & $0.0 \pm 0.0 \mathrm{Ab}$ & $21.01 \mathrm{~A}$ \\
\hline \multirow{3}{*}{5} & $\mathrm{D} 12 \mathrm{~A}$ & $100.0 \pm 0.0 \mathrm{Aa} 100.0 \pm 0.0 \mathrm{Aa}$ & $9.68 \pm 1.7 \mathrm{Aa}$ & $0.0 \pm 0.0 \mathrm{Aa}$ & $0.0 \pm 0.0 \mathrm{Aa}$ & $0.0 \pm 0.0 \mathrm{Aa}$ & $34.95 \mathrm{~A}$ \\
\hline & D16 & $100.0 \pm 0.0 \mathrm{Aa} 100.0 \pm 0.0 \mathrm{Aa}$ & $27.5 \pm 2.5 \mathrm{Aa}$ & $0.0 \pm 0.0 \mathrm{Aa}$ & $0.0 \pm 0.0 \mathrm{Aa}$ & $0.0 \pm 0.0 \mathrm{Aa}$ & $37.92 \mathrm{~A}$ \\
\hline & D30 & $100.0 \pm 0.0 \mathrm{Aa} 0.0 \pm 0.0 \mathrm{Ab}$ & $0.0 \pm 0.0 \mathrm{Ab}$ & $0.0 \pm 0.0 \mathrm{Ab}$ & $0.0 \pm 0.0 \mathrm{Ab}$ & $0.0 \pm 0.0 \mathrm{Ab}$ & $16.67 \mathrm{~B}$ \\
\hline
\end{tabular}


Table 5. Sensitivity of Mycogone perniciosa isolates to ozonation, based on the percentage of growth inhibition

\begin{tabular}{|c|c|c|c|c|c|c|}
\hline \multirow{2}{*}{ Days } & \multirow{2}{*}{ Isolate } & \multicolumn{4}{|c|}{ Time of exposure } & \multirow{2}{*}{ Mean } \\
\hline & & $4 \mathrm{~h}$ & $2 \mathrm{~h}$ & $1 \mathrm{~h}$ & $0.5 \mathrm{~h}$ & \\
\hline \multirow{3}{*}{4} & M9 & $100.0 \pm 0.0 \mathrm{Aa} 100.0 \pm 0.0 \mathrm{Aa} 77.4 \pm 7.1 \mathrm{Aab}$ & $51.60 \pm 17.1 \mathrm{Aab}$ & $25.51 \pm 11.7 \mathrm{Ab}$ & $0.0 \pm 0.0 \mathrm{Ab}$ & $59.08 \mathrm{~A}$ \\
\hline & M10 & $100.0 \pm 0.0 \mathrm{Aa} 100.0 \pm 0.0 \mathrm{Aa} 52.81 \pm 15.0 \mathrm{Ab}$ & $8.18 \pm 5.2 \mathrm{Ab}$ & $5.52 \pm 3.7 \mathrm{Ab}$ & $0.0 \pm 0.0 \mathrm{Ab}$ & $44.42 \mathrm{~A}$ \\
\hline & M18 & $100.0 \pm 0.0 \mathrm{Aa} 100.0 \pm 0.0 \mathrm{Aa} 22.58 \pm 6.5 \mathrm{Ab}$ & $18.22 \pm 9.4 \mathrm{Ab}$ & $14.40 \pm 3.8 \mathrm{Ab}$ & $0.0 \pm 0.0 \mathrm{Ab}$ & $42.53 \mathrm{~A}$ \\
\hline \multirow{3}{*}{5} & M9 & $100.0 \pm 0.0 \mathrm{Aa} 100.0 \pm 0.0 \mathrm{Aa} 69.39 \pm 9.3 \mathrm{Aa}$ & $29.56 \pm 9.5 \mathrm{Ab}$ & $8.32 \pm 3.2 \mathrm{Ab}$ & $0.0 \pm 0.0 \mathrm{Ab}$ & $51.2 \mathrm{~A}$ \\
\hline & M10 & $100.0 \pm 0.0 \mathrm{Aa} 100.0 \pm 0.0 \mathrm{Aa} 36.38 \pm 9.0 \mathrm{Ab}$ & $32.41 \pm 11.5 \mathrm{Ab}$ & $5.20 \pm 3.1 \mathrm{Ab}$ & $0.0 \pm 0.0 \mathrm{Ab}$ & $45.7 \mathrm{~A}$ \\
\hline & M18 & $100.0 \pm 0.0 \mathrm{Aa} 100.0 \pm 0.0 \mathrm{Aa} 14.5 \pm 2.2 \mathrm{Ab}$ & $5.61 \pm 4.9 \mathrm{Ab}$ & $5.01 \pm 3.2 \mathrm{Ab}$ & $0.0 \pm 0.0 \mathrm{Ab}$ & $37.5 \mathrm{~A}$ \\
\hline \multirow{3}{*}{6} & M9 & $100.0 \pm 0.0 \mathrm{Aa} 100.0 \pm 0.0 \mathrm{Aa} 54.84 \pm 6.8 \mathrm{Aab}$ & $44.67 \pm 15.3 \mathrm{Aab}$ & $6.95 \pm 1.7 \mathrm{Ab}$ & $0.0 \pm 0.0 \mathrm{Ab}$ & $51.08 \mathrm{~A}$ \\
\hline & M10 & $100.0 \pm 0.0 \mathrm{Aa} 100.0 \pm 0.0 \mathrm{Aa} 15.47 \pm 8.6 \mathrm{Ab}$ & $8.83 \pm 3.6 \mathrm{Ab}$ & $5.11 \pm 1.3 \mathrm{Ab}$ & $0.0 \pm 0.0 \mathrm{Ab}$ & $38.24 \mathrm{~A}$ \\
\hline & M18 & $100.0 \pm 0.0 \mathrm{Aa} 100.0 \pm 0.0 \mathrm{Aa} 10.82 \pm 8.6 \mathrm{Ab}$ & $8.32 \pm 3.3 \mathrm{Ab}$ & $6.25 \pm 1.3 \mathrm{Ab}$ & $0.0 \pm 0.0 \mathrm{Ab}$ & $37.57 \mathrm{~A}$ \\
\hline \multirow{3}{*}{7} & M9 & $100.0 \pm 0.0 \mathrm{Aa} 100.0 \pm 0.0 \mathrm{Aa} 15.45 \pm 9.3 \mathrm{Aa}$ & $24.85 \pm 8.4 \mathrm{Aa}$ & $0.0 \pm 0.0 \mathrm{Aa}$ & $0.0 \pm 0.0 \mathrm{Aa}$ & $40.05 \mathrm{~A}$ \\
\hline & M10 & $100.0 \pm 0.0$ Aa $100.0 \pm 0.0$ Aa $7.5 \pm 2.9$ Aa & $4.49 \pm 2.0 \mathrm{Aa}$ & $0.0 \pm 0.0 \mathrm{Aa}$ & $0.0 \pm 0.0 \mathrm{Aa}$ & $35.33 \mathrm{~A}$ \\
\hline & M18 & $100.0 \pm 0.0$ Aa $100 \pm 0.0 \mathrm{Aa} \quad 7.25 \pm 2.1 \mathrm{Ab}$ & $0.0 \pm 0.0 \mathrm{Ab}$ & $0.0 \pm 0.0 \mathrm{Ab}$ & $0.0 \pm 0.0 \mathrm{Ab}$ & $34.54 \mathrm{~A}$ \\
\hline
\end{tabular}

Note: See Table 3

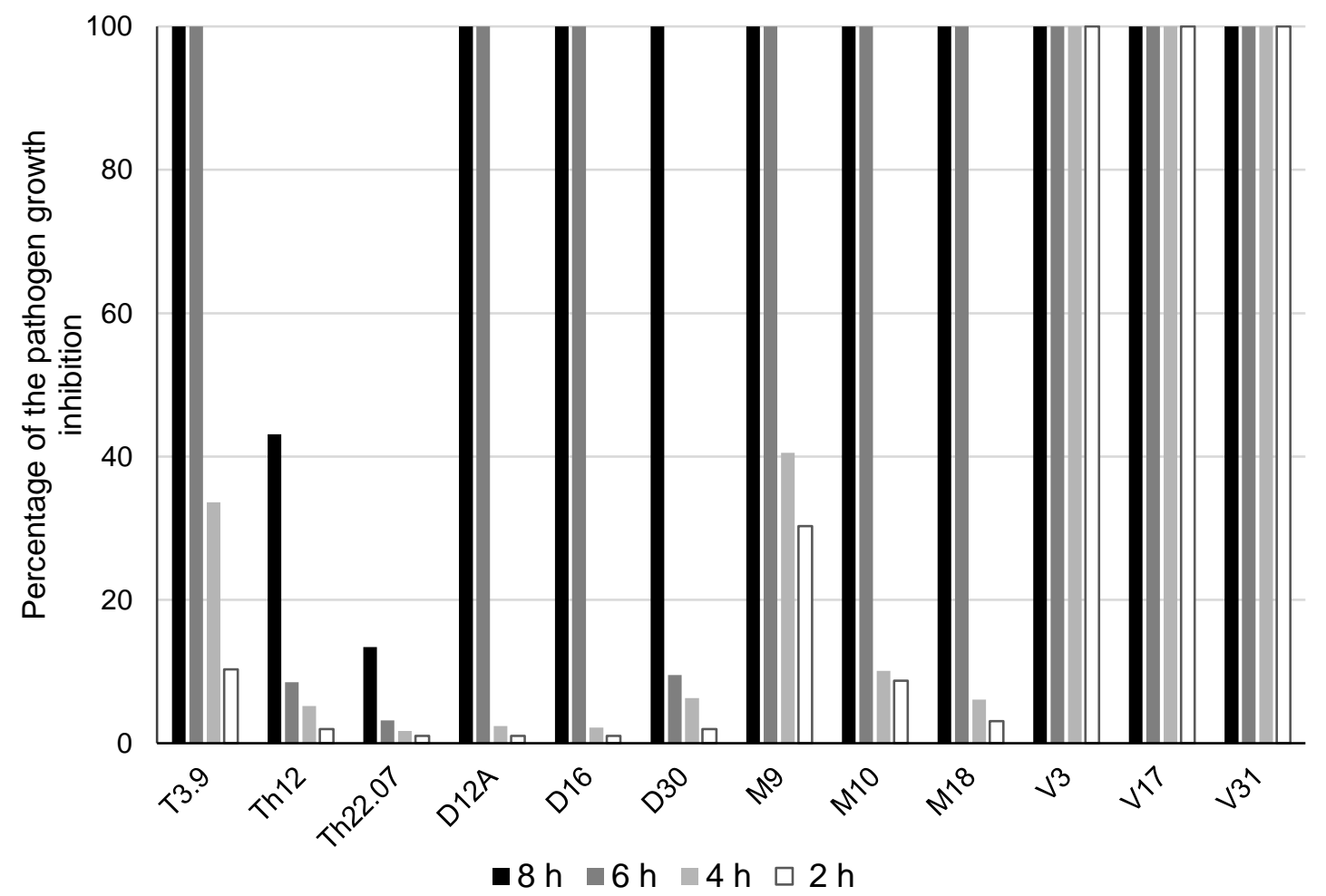

Fig. 3. Percentage of the growth inhibition of pathogens after different exposure times to ozonation 
The phenomenon of diversity of isolates within one species was also observed by SzumigajTarnowska et al. (2015). The authors showed that individual isolates of M. perniciosa differ in pathogenicity in relation to the button mushroom. For example, the isolate $M$. perniciosa M9 was the most tolerant to ozonation among all the tested isolates and also the most virulent to A. bisporus (SzumigajTarnowska et al. 2015).

Unfortunately, there are no published scientific data on the effect of ozone on spores of M. perniciosa, C. dendroides, and L. fungicola. In our study, all these species showed high susceptibility to ozone gas. In order to achieve $100 \%$ efficacy against Mycogone isolates, a minimum of 6 hours of ozonation had to be applied, whereas for Cladobotryum strains, a minimum of 8 hours had to be applied (Table 2). Individual isolates of Cladobotryum differed in their sensitivity to ozonation. Two isolates were completely inhibited after 6 hours of ozone, whereas for inhibition of isolate Cladobotryum spp. D30 growth, a minimum of 8 hours of ozonation was required (Fig. 3).

The Lecanicillium isolates were particularly sensitive to ozonation as only 30 minutes was sufficient to gain total inhibition of its mycelium growth. That is why the diameter of its colonies after ozonation was not recorded on Fig. 3, where results concern exposure ranging from 2 to 8 hours.

However, the experiments presented by Luković et al. (2018) showed also the high sensitivity of L. fungicola to some essential oils. Inhibitory and fungicidal activity of the selected essential oils was assayed using microdilution and macrodilution fumigant methods. And what is more, Lecanicillium isolate was more sensitive to tested oils than Cladobotryum isolate. These results indicated that Lecanicillium isolates can be highly sensitive to various biological substances and non-synthetic factors. Galvão and Bettiol (2014) showed the high susceptibility of Lecanicillium genera to UV-B radiation, while Mehrparvar et al. (2016) determined the antifungal activity of two essential oils at low concentrations for the growth of L. fungicola.
According to the findings of Antony-Babu and Singleton (2009), gas ozone is more effective in reducing spore germination than in reducing mycelial growth. In our research, fungal spores were exposed to gaseous ozone. Probably, this is the reason why ozonation efficiency was so high in relation to the tested pathogens.

The time of ozone exposure was highly correlated with inhibition of the growth of Trichoderma, Mycogone, and Cladobotryum isolates $(\mathrm{r}=0.969$, $r=0.960$, and $r=0.908$, respectively) (Fig. 2).

Therefore, we conclude that short-term ( 0.5 hour) ozonation can be suitable for disinfection of growing rooms at the end of the cultivation cycle only for infection caused by L. fungicola. Longterm (6-8 hours) ozonation may be useful for disinfection of empty growing rooms for M. perniciosa and $C$. dendroides, whereas ozonation with a concentration of $50 \mathrm{ppm}$ may be ineffective in relation to the pathogenic isolates of Trichoderma.

\section{Acknowledgments}

This study was supported by the Ministry of Science and Higher Education. The research was carried out under the statutory activity at the Research Institute of Horticulture in Skierniewice (Research topic 4.4.2).

\section{REFERENCES}

Akata I., Torlak E., Erci F. 2015. Efficacy of gaseous ozone for reducing microflora and foodborne pathogens on button mushroom. Postharvest Biology and Technology 109: 40-44. DOI: 10.1016/j.postharvbio.2015.06.008.

Antony-Babu S., Singleton I. 2009. Effect of ozone on spore germination, spore production and biomass production in two Aspergillus species. Antonie van Leeuwenhoek 96(4): 413-422. DOI: 10.1007/s10482-009-9355-2.

Baars J., Rutjens J. 2016. Finding a suitable biocide for use in the mushroom industry. Proceedings of the XIX International Congress on the Science and Cultivation of Edible and Medicinal Fungi, Amsterdam, the Netherlands, 30 May-2 June, pp. 114-117. 
Berendsen R.L., Baars J.J.P., Kalkhove S.I.C., Lugones L.G., Wösten H.A.B., Bakker P.A.H.M. 2010. Lecanicillium fungicola: causal agent of dry bubble disease in whitebutton mushroom. Molecular Plant Pathology 11: 585-595. DOI: 10.1111/j.1364-3703.2010.00627.x.

Buntat Z., Razali M.C., Buntat Y. 2013. Experimental study of ozone treatment system for mushroom substrates sterilization. Advanced Science Letters 19(11): 3135-3138. DOI: 10.1166/asl.2013.5143.

Ekman J. 2017. Pre- and postharvest management of mushrooms. A Review. Horticulture Innovation Australia Limited, Sydney, 59 p.

Escriche I., Serra J.A., Gómez M., Galotto M.J. 2001. Effect of ozone treatment and storage temperature on physicochemical properties of mushrooms (Agaris bisporus). Food Science and Technology International 7(3): 251-258. DOI: 10.1106/6a9r-dkev$\operatorname{adv} 7-y 30 x$.

Fletcher J.T., Gaze R.H. 2008. Mushroom pest and disease control: A colour handbook. Manson Publishing, London, 192 p.

Galvão J.A.H., Bettiol W. 2014. Effects of UV-B radiation on Lecanicillium spp., biological control agents of the coffee leaf rust pathogen. Tropical Plant Pathology 39(5): 392-400. DOI: 10.1590/s1982-56762014000500006.

Hudson J.B., Sharma M. 2009. The practical application of ozone gas as an anti-fungal (anti-mold) agent. Ozone: Science and Engineering 31: 326-332. DOI: 10.1080/01919510903043996.

Krosowiak K., Śmigielski K., Dziugan P. 2007. Zastosowanie ozonu w przemyśle spożywczym. Przemysł Spożywczy 11: 26-29. [in Polish with English abstract]

Kaliyaperumal M., Kezo K., Gunaseelan S. 2018. A Global Overview of Edible Mushrooms. In: Singh B.P., Lallawmsanga, Passari A.K. (Eds.), Biology of Macrofungi. Fungal Biology. Springer, pp. 15-56. DOI: 10.1007/978-3-030-02622-6_2.

Kapahi M. 2018. Recent Advances in Cultivation of Edible Mushrooms. In: Singh B.P., Lallawmsanga, Passari A.K. (Eds.), Biology of Macrofungi. Fungal Biology. Springer, pp. 275-286. DOI: 10.1007/978-3-030-02622-6_13.

Luković J., Stepanović M., Todorović B., MilijaševićMarčić S., Duduk N., Vico I., Potočnik I. 2018. Antifungal activity of cinnamon and clove essential oils against button mushroom pathogens Cladobotryum dendroides (Bull.) W. Gams \& Hooz and Lecanicillium fungicola var. fungicola (Preuss) Hasebrauk. Pesticides and Phytomedicine 33(1): 19-26. DOI: 10.2298/pif18010191.

Mehrparvar M., Goltapeh E.M., Safaie N., Ashkani S., Hedesh R.M. 2016. Antifungal activity of essential oils against mycelial growth of Lecanicillium fungicola var. fungicola and Agaricus bisporus. Industrial Crops and Products 84: 391-398. DOI: 10.1016/j.indcrop.2016.02.012.

O’Brien M., Kavanagh K., Grogan H. 2017. Detection of Trichoderma aggressivum in bulk phase III substrate and the effect of T. aggressivum inoculum, supplementation and substrate-mixing on Agaricus bisporus yields. European Journal of Plant Pathology 147: 199-209. DOI: 10.1007/s10658-016-0992-9.

O’Neill T., Lole M., Drakes D. 2015. Use of chemical disinfectants in mushroom production. MushTV. Factsheet 01/15; 8 p. https://www.teagasc.ie/me$\mathrm{dia} /$ website/publications/2015/Use-of-chemicaldisinfectants.pdf

Rodríguez A., Rosal R., Perdigón-Melón J.A., Mezcua M., Agüera A., Hernando M.D. et al. 2008. Ozonebased technologies in water and wastewater treatment. Handbook in Environmental Chemistry 5S2: 127-175. DOI: 10.1007/698_5_103.

Sánchez C. 2010. Cultivation of Pleurotus ostreatus and other edible mushrooms. Applied in Microbiology and Biotechnology 85: 1321-1337. DOI: 10.1007/s00253-009-2343-7.

Skalska K., Ledakowicz S., Senico B., Perkowski J. 2006. Wykorzystanie ozonu jako środka dezynfekującego. IV Międzynarodowa Konferencja Naukowa. Corrosion Protection 9s/A: 338341. [in Polish]

Szczech M., Staniaszek M., Habdas H., Uliński Z., Szymański J. 2008. Trichoderma spp. - the cause of green mold on polish mushroom farms. Vegetable Crops Research Bulletin 69: 105-114. DOI: 10.2478/v10032-008-0025-0.

Skog L.J., Chu C.L. 2001. Effect of ozone on qualities of fruits and vegetables in cold storage. Canadian Journal of Plant Science 81(4): 773-778. DOI: 10.4141/p00-110.

Szumigaj-Tarnowska J., Uliński Z., Ślusarski C., Szymański J. 2011. Susceptibility of the various strains of the 
cultivated mushrooms to the fungal pathogen Lecanicillium fungicola (Verticillium fungicola). Progress in Plant Protection/Postępy w Ochronie Roślin 51(3): 1203-1206. [in Polish with English abstract] Szumigaj-Tarnowska J., Szczechura W., Staniaszek M., Uliński Z., Ślusarski C. 2014. Identification and assessment of genetic diversity of the fungal pathogen Mycogone perniciosa using PCR method. XI Conference of the European Foundation for Plant Pathology, 8-13 September, Kraków, Poland. Book of Abstracts; S3.P36; p. 223.

Szumigaj-Tarnowska J., Ślusarski C., Uliński Z. 2015. Pathogenicity of Mycogone perniciosa isolates collected on Polish mushroom farms. Journal of Horticultural Research 23(1): 87-92. DOI: 10.2478/johr-2015-0011.

Ślusarski C., Uliński Z., Szumigaj-Tarnowska J. 2012. A survey of the sanitary conditions and the occurrence of infectious diseases on Polish mushroom farms.
Progress in Plant Protection/Postępy w Ochronie Roślin 52(4): 1052-1057. DOI: 10.14199/ppp-2012-182. [in Polish with English abstract]

Ślusarski C., Uliński Z., Szumigaj-Tarnowska J. 2013. Evaluation of the tolerance of selected white button mushroom strains to two species of Cladobotryum, causing cobweb disease. Episteme 20(1): 559-567. [in Polish with English abstract]

Toto R. 2010. Ozone treatment of mushroom house. US Patent 7647725 B2.

Trzewik A., Szumigaj-Tarnowska J., Szymański J. 2010. Identification of Verticillium fungicola, isolates causing dry bubble of white button mushrooms. Zeszyty Problemowe Postępów Nauk Rolniczych 554: 261-266 [in Polish with English abstract]

Vanachter A., Thys L., Van Wambeke E., Van Assche C. 1988. Possible use of ozone for disinfestation of plant nutrient solutions. Acta Horticulturae 221: 295-302. DOI: 10.17660/actahortic.1988.221.32. 